\title{
Colonization and Movement of Xanthomonas fragariae in Strawberry Tissues
}

\author{
Hehe Wang, Christine McTavish, and William W. Turechek ${ }^{\dagger}$
}

First author: Department of Plant and Environmental Sciences, Clemson University, Blackville, SC; second author: U.S. Department of Agriculture-Agricultural Research Service (USDA-ARS), Physiology and Pathology of Tree Fruits Research, Wenatchee, WA; and third author: USDA-ARS, U.S. Horticultural Research Laboratory, Fort Pierce, FL.

Accepted for publication 24 December 2017.

\begin{abstract}
Xanthomonas fragariae causes angular leaf spot of strawberry, an important disease in strawberry growing regions worldwide. To better understand how $X$. fragariae multiplies and moves in strawberry plants, a green fluorescent protein (GFP)-labeled strain was constructed and used to monitor the pathogen's presence in leaf, petiole, and crown tissue with fluorescence microscopy following natural and wound inoculation in three strawberry cultivars. Taqman PCR was used to quantify bacterial densities in these same tissues regardless of the presence of GFP signal. Results showed $X$. fragariae colonized leaf mesophyll, the top $1 \mathrm{~cm}$ portion of the petiole adjacent to the leaf blade, and was occasionally found colonizing xylem vessels down to the middle of the petioles. The colonization of vascular

bundles and the limited systemic movement that was observed appeared to be a passive process, of which the frequency increased with wounding and direct infiltration of bacteria into leaf veins. $X$. fragariae was able to directly enter petioles and colonize the space under the epidermis. Systemic movement of the bacteria into crown and other uninoculated tissues was not detected visually by GFP. However, $X$. fragariae was occasionally detected in these tissues by qPCR, but at quantities very near the qPCR detection limit. Petiole tissue harboring bacteria introduced either by direct entry through natural openings or wounds, or by systemic movement from infected foliar tissue, likely serves as a main source of initial inoculum in field plantings.
\end{abstract}

Xanthomonas fragariae is a bacterium that causes angular leaf spot (ALS) of strawberry, an important disease in strawberry production regions worldwide, particularly in nursery production (López et al. 2006; Maas et al. 1995; Smith et al. 1992). This bacterium most notably attacks the foliage and calyxes of the plant. Infected plants first develop water-soaked, semitranslucent angular lesions on the lower leaf surface. The borders of lesions, particularly young lesions, are angular in appearance as a result of being restricted by the surrounding leaf veins. Strawberry leaves have a reticulate venation pattern and lesions can be confined by any of the main, secondary or tertiary veins. As lesions age, they tend to produce reddish-brown, irregular spots on the upper leaf surface, which usually coalesce to form larger patches that may or may not be accompanied by a diffuse yellowing of the surrounding leaf tissue. Angular spots also develop on calyxes and, during severe infection, the whole calyx dries out and darkens causing a symptom known as "black cap." In addition to leaf and calyx infections, $X$. fragariae has been reported to colonize vascular tissues and in extreme cases invade the crown and cause plant collapse (Hildebrand et al. 1967).

$X$. fragariae survives in or on strawberry plant tissue during cold storage where it can be transmitted to nursery- or fruit-production fields through contaminated or latently infected nursery stock (Hildebrand et al. 1967; Maas et al. 1995). Under favorable environmental conditions, the pathogen multiplies and oozes from the undersides of leaf lesions to form a large quantity of secondary

†Corresponding author: W. W. Turechek; E-mail: william.turechek@ars.usda.gov

Funding: Funding for this work was supported through the U.S. Department of Agriculture-Foreign Agricultural Service-Technical Assistance for Specialty Crops Grant 2012-51 and the U.S. Department of Agriculture-Current Research Information System 6034-22000-039-00D.

This article is in the public domain and not copyrightable. It may be freely reprinted with customary crediting of the source. The American Phytopathological Society, 2018. inoculum. Secondary spread occurs by both splash dispersal during rain or irrigation events, and by mechanical means that occur during the removal of blossoms (a nursery practice) and harvesting, for example (Gigot et al. 2017). Plantings are particularly vulnerable to ALS in regions where rain is prevalent during the production season and/or where overhead irrigation is used for frost protection. Currently, there are no strawberry varieties fully resistant to disease and no effective chemical treatments commercially available in the United States.

In fruit production fields, ALS can reduce fruit yield when infection is severe, and unsightly infections of the calyx can render fruit unmarketable. However, the biggest monetary impact of ALS on the U.S. industry is on the international trade of nursery stock. Losses occur when plants are rejected by inspectors due to violations of quarantine regulations. For example, to export strawberry plants to Europe, the European and Mediterranean Plant Protection Organization (EPPO) mandates that nurseries maintain phytosanitary standards including that planting material be derived from mother plants certified free of $X$. fragariae, and production sites be documented free from ALS for the past five growing seasons (López et al. 2006; Smith et al. 1992). Based on estimates from the strawberry nursery industry, annual production losses due to ALS range from 5 to $8 \%$ industry-wide, valued between $\sim \$ 700,000$ and $\$ 1,100,000$ (C. Winterbottom, personal communication). For individual nurseries, losses can be as low as $2 \%$ to as high as $30 \%$ depending on their market.

ALS has become increasingly problematic over the past 10 years. To improve disease management, it is important to understand how the pathogen colonizes and moves within plants and to identify the tissues that could serve as inoculum sources. Like other leaf-spotting Xanthomonads, it was shown that $X$. fragariae enters leaf tissue through openings, such as stomata and wounds, colonizes the intercellular space of leaf mesophyll with a biofilm, causing plant cell plasmolysis and deformation, and oozes out the leaf surface though stomata (AllanWojtas et al. 2010; Hildebrand et al. 2005; Kastelein et al. 2014). Generally speaking, leaf-spotting bacteria are typically nonvascular-invading pathogens (Aiello et al. 2013; Jacques et al. 2016; Pfeilmeier et al. 2016; Ryan et al. 2011). However, some 
previous studies have reported $X$. fragariae in strawberry vascular tissue (Hildebrand et al. 1967; Milholland et al. 1996) and/or its presence in tissues away from the site of inoculation (Bestfleisch et al. 2015; Milholland et al. 1996; Stefani et al. 1989). Using immunofluorescence staining (IFAS), Stefani et al. (1989) isolated bacteria "very similar" to X. fragariae from a small proportion of crown samples (8\%) 2 months after leaf inoculation. Milholland et al. (1996), in perhaps the most cited study on this topic, isolated X. fragariae from nearly $100 \%$ of their petiole-tissue samples 2 weeks after foliar inoculation and from 12.5 and $83 \%$ of their crown-tissue samples 12 weeks after inoculation (a fairly large discrepancy between experimental repeats). They also observed the bacteria in petiole xylem vessels through microscopy. More recently, using a green fluorescent protein (GFP)-labeled strain and nested-PCR (Zimmermann et al. 2004), Bestfleisch et al. (2015) showed a rapid and systemic spread of $X$. fragariae to all the systemic (uninoculated) tissues tested as early as 3 days after foliar inoculation.

The collective findings reported in these earlier studies do not point to a single mechanism explaining how $X$. fragariae moves and survives in strawberry plant tissue. The discrepancies among the studies may be attributed to factors associated with experimental design including the use of different strawberry varieties, $X$. fragariae strains, small sample sizes, limited replication, or to procedural factors such as how plants were watered after inoculation. Any overhead watering, no matter how brief, can redistribute the bacteria on inoculated plants and obscure results. Therefore, to better understand how $X$. fragariae multiplies and moves in strawberry plants, a GFP-labeled strain was constructed and the pathogen's presence in leaf, petiole, and crown tissues was examined with fluorescence microscopy and Taqman PCR following different inoculation methods and watering regimes.

\section{MATERIALS AND METHODS}

Construction of the GFP strain and preparation of bacterial culture. The plasmid p519ngfp (Matthysse et al. 1996) was extracted from Escherichia coli (ATCC87453) and $1 \mu \mathrm{l}(\sim 100 \mathrm{ng} / \mu \mathrm{l})$ of extract was electroporated into $X$. fragariae strain Xf100 competent cells in $10 \%$ glycerol $\left(50 \mu \mathrm{l}, \sim 10^{11} \mathrm{CFU} / \mathrm{ml}\right)$ in $2 \mathrm{~mm}$ cuvettes. Electroporation was done in an Eppendorf Electroporator 2510 at $1,800 \mathrm{kV}$ for 1 to $2 \mathrm{~s}$ at $4^{\circ} \mathrm{C}$. Electroporated cells were shaken at room temperature for $4 \mathrm{~h}$ in sucrose-peptone broth (SPB) (Hayward 1960) before being plated (100 to $200 \mu$ l per plate) on sucrose peptone agar (SPA) (Hayward 1960) amended with kanamycin at $50 \mathrm{ng} / \mu \mathrm{l}$. After 7 days of growth, the transformed colonies were selected for presence of green fluorescence (482 nm) under Olympus SZX16 microscope equipped with a GFP filter, and confirmed by PCR and direct sequencing with GFPmut2 primers (forward: CGGGAACTACAAGACACGTGCTGA, reverse: AAGGACAGGGCCATCGCCAA) and $X$. fragariae-specific primers 295AB (Pooler et al. 1996). Single fluorescent colonies were transferred to SPB on an orbital table shaker to grow for 2 days. The bacterial suspensions were centrifuged at $3,000 \times g$ for $3 \mathrm{~min}$, resuspended in sterilized distilled water, and adjusted to an optical density $\left(\mathrm{OD}_{620}\right)$ of 0.1 , which is equivalent to $\sim 10^{8} \mathrm{CFU} / \mathrm{ml}$ (Hazel and Civerolo 1980; Wang and Turechek 2016). To confirm pathogenicity and determine virulence relative to the wild type, the transformants were inoculated onto disease-free strawberry plants (cultivars Festival, Ventana, Darselect, Portola, and Camino Real) and maintained in the greenhouse. Stability of the GFP signal in inoculated leaves was determined by regularly monitoring the GFP signal in bacterial colonies on SPA plates as well as in strawberry leaves for 8 weeks after inoculation. The successful transformant was designated as Xf100-GFP.

Spray inoculation. Splash dispersal is the most common method of dispersal for $X$. fragariae in the field. Thus, spray inoculation was used to mimic natural dispersal to investigate bacterial colonization and movement in plants. A water suspension of Xf100-GFP inoculum $\left(10^{8}\right.$ $\mathrm{CFU} / \mathrm{ml}$ ) was carefully sprayed on to the underside of the three youngest fully expanded strawberry leaves with a handheld fine-mist sprayer (Boston Round Bottle, U.S. Plastic Corp., Lima, OH). The other plant tissues were shielded from inoculation with our hands to prevent inoculated leaves from touching the other plant parts; nitrile gloves were worn and rubbed with $70 \%$ ethyl alcohol between inoculations. Control plants were inoculated with water. All plants were placed in a walk-in growth chamber with $12 \mathrm{~h}$ photoperiod, $25^{\circ} \mathrm{C}$ and $60 \%$ relative humidity (RH) during day, and $15^{\circ} \mathrm{C}$ and $90 \% \mathrm{RH}$ during night. Drip irrigation was applied to the pots to eliminate any additional wetting of leaf surfaces, and samples were collected (described below) at 1 day after inoculation (dai) and then 1, 2, 4, 6, 8, 10, and 12 weeks after inoculation (wai). The experiment was conducted using three cultivars (cultivars Festival, Ventana, and Darselect) with three replicate plants for each sampling period for the inoculated plants (except for Darselect where only two replicate plants were used) and two replicate plants for each sampling period for the controls. The experiment was repeated once using Festival. Note: Due to space limitations, Ventana was included for only the spray inoculation portion of the experiment.

Wound inoculation. The likelihood of systemic movement was further investigated with three wound-inoculation methods on Festival and Darselect. Strawberry leaves were inoculated with a $10^{8} \mathrm{CFU} / \mathrm{ml}$ water suspension of Xf100-GFP by (i) gentle rubbing of the underside of leaves with cheesecloth dipped in the inoculum suspension and then mixed with sand (RUB); (ii) pressure-infiltration into underside of leaves between secondary veins with a $(3 \mathrm{~mm}$ diameter) needleless syringe (IBV); or (iii) pressure-infiltration directly into secondary veins on the underside of leaves with a needleless syringe (IDV). For infiltrated inoculation, four locations between the center and bottom portions of the leaf blade were inoculated. The three youngest fully expanded leaves were inoculated on each plant. Control plants were inoculated with water. Inoculated plants were maintained in a greenhouse with drip irrigation. Samples were collected at 1 dai, and 1, 2, 4, 6, 8, 10, and 12 wai. The experiment was conducted once with Festival and once with Darselect, with three replicate plants used for inoculated samples (except Darselect where only two replicates were used) and two replicate plants for the control in each experiment.

Whole-plant inoculation and watering regime. In addition to leaf inoculation, whole plants were spray inoculated to include all above-ground tissues, i.e., leaf tissue, petioles, and crowns. Inoculated plants were kept in the growth chamber with a $12 \mathrm{~h}$ photoperiod at $25^{\circ} \mathrm{C}$ and $60 \% \mathrm{RH}$ during day, and $15^{\circ} \mathrm{C}$ and $90 \% \mathrm{RH}$ during night (the same conditions described above). A total of 21 plants were inoculated with Xf100-GFP suspension $\left(10^{8} \mathrm{CFU} / \mathrm{ml}\right)$ and 14 plants were inoculated with water to serve as control plants. One-half of the plants were dripirrigated while the other half received over-head watering once every 2 weeks to simulate rainfall and allow reinoculation. Samples were collected at 1 dai, and 2, 4, 6, 8, 10, and 12 wai. The experiment was conducted once with Festival, with three replicate plants for inoculated samples and two replicates for the control.

Tissue sampling and microscopy examination. At each sampling period, samples were taken from the leaves, petioles, and crown of the three replicate inoculated plants and two control plants. The three inoculated leaves per plant were examined separately under GFP luminescence on an Olympus SZX16 microscope for symptoms. The leaves were then combined for DNA extraction as described below. The petiole for each inoculated leaf was taken and cut into three $1 \mathrm{~cm}$ sections (top, middle, and bottom). Each section was thinly sliced with a razor blade and placed on glass slides for examination under GFP luminescence on an Olympus BX41 epifluorescent microscope (Olympus, Tokyo, Japan). Thereafter, the three petiole sections per plant from each position (top, middle, or bottom) were combined for DNA extraction as described below. For crown tissue, the top $1 \mathrm{~cm}$ section per plant was first visually examined for GFP signal under the microscope, and then processed for DNA extraction as described below.

For wound-inoculated plants, additional samples were collected as above from a single newly emerged leaf from each plant. For each leaf, all three petiole sections (top, middle, and bottom) were combined for DNA extraction. DNA was extracted for each leaf separately (described below). 
DNA extraction. Each leaf sample was ground in liquid nitrogen and $100 \mathrm{mg}$ of homogenized tissue was used for DNA extraction. Petiole samples were macerated with two nickel-plated steel balls (K\&J Magnetics Inc., Pipersville, PA) in 1,000 $\mu$ l of distilled water. After beating on a Mini Beadbeater-96 (Biospec Products Inc., Bartlesville, OK) for $3 \mathrm{~min}, 500 \mu \mathrm{l}$ of tissue suspension was pipetted into a 2-ml microcentrifuge tube and centrifuged at 20,000 $\times g$ for $5 \mathrm{~min}$. The supernatant was decanted and the pellet was used for DNA extraction. Each crown sample (each $1 \mathrm{~cm}$ section was $\sim 1 \mathrm{~g}$ ) was separated into four screw-capped microcentrifuge tubes for maceration following the same protocol for petiole samples. Thereafter, $125 \mu \mathrm{l}$ of tissue suspension was taken from each tube and combined as a $500-\mu \mathrm{l}$ suspension in a new 2-ml microcentrifuge tube, which was centrifuged at $20,000 \times g$ for $5 \mathrm{~min}$ to prepare the pellet for DNA extraction.

DNA was extracted with the Qiagen DNeasy Plant Mini Kit (Qiagen, CA) using the modified protocol first described in Wang and Turechek (2016). AP1 buffer was amended with 4\% PVP-40 (Sigma-Aldrich, St. Louis, MO) for better removal of PCR-inhibitors from the strawberry tissues. Each sample was suspended in $550 \mu \mathrm{l}$ of AP1 buffer and incubated at $65^{\circ} \mathrm{C}$ for $10 \mathrm{~min}$. Samples were then mixed with $180 \mu \mathrm{l}$ of P3 buffer, processed following manufacturer's protocol, and then eluted in $200 \mu \mathrm{l}$ of AE buffer.

Taqman-PCR. Taqman PCR primers q295 specific for $X$. fragariae were used exclusively in this study for bacteria quantification (Turechek et al. 2008). Each 20- $\mu$ l qPCR reaction contained $2 \mu \mathrm{l}$ of DNA template, $0.36 \mu \mathrm{M}$ of forward and reverse primers, $0.17 \mu \mathrm{M}$ of the Taqman probe, and $1 \times$ master mix from the DyNAmo Flash Probe qPCR Kit (Thermo Fisher Scientific, Pittsburgh, PA). The reactions were run in an Eppendorf Realplex ${ }^{4}$ master cycler at $95^{\circ} \mathrm{C}$ for $7 \mathrm{~min}$, followed by 40 cycles of $95^{\circ} \mathrm{C}$ for $10 \mathrm{~s}$ and $55^{\circ} \mathrm{C}$ for $30 \mathrm{~s}$. In each run, a 10-fold DNA dilution series from $10^{9}$ to $10^{3} \mathrm{CFU} / \mathrm{ml}$ of Xf100-GFP strain (yielding $\mathrm{C}_{t}$ values between 18 and 37.8) and a nontemplate control were included $\left(C_{t}=40\right)$. Each sample was run in two technical replicates.

Data analysis. For all samples, bacterial densities (i.e., CFU/ sample) were estimated from the standard curves included in their respective qPCR runs; where a "sample" is equivalent to $100 \mathrm{mg}$ of leaf tissue, a $1 \mathrm{~cm}$ section of petiole, and a $1 \mathrm{~cm}$ section of crown tissue. Means and standard errors of bacterial densities were calculated for each treatment (i.e., each combination of cultivar $\times$ inoculation method $\times$ watering regime) from the replicates per sampling period. The qPCR assay has near perfect sensitivity up to $\sim 10^{4} \mathrm{CFU} / \mathrm{ml}$, which was equivalent to $\sim 10$ bacteria cells per PCR reaction $\left(C_{t} \sim 34\right)$ (Turechek et al. 2008; Wang and Turechek 2016). The nontemplate controls almost always produced $\mathrm{C}_{\mathrm{t}}$ values of 40 , which despite the absence of any $X$. fragariae DNA, equates to $\sim 200$ CFU/sample based on estimates derived from the standard curves.

The dependent variables CFU/sample for (i) leaf tissue, (ii) petiole sections (top and bottom), and (iii) crown tissue averaged over the evaluation period ( 0 to 12 wai for Festival and Darselect, and 0 to 10 wai for Ventana) were analyzed individually in a generalized linear mixed model (GLMM) using the SAS procedure GLIMMIX (SAS, ver. 9.1, Cary, NC), specifying an identity link function and Gaussian (normal) error distribution. Each dependent variable was log transformed prior to analysis. The independent variables "treatment" and "time" were treated as fixed effects, and "replication" and "experiment" (for cultivar Festival only) were treated as random effects. No interaction terms were examined in these analyses. Standardized residual and normality plots were used to determine the adequacy of model fit. Pairwise treatment differences for the main effects were obtained using the LSMEANS statement and LINES option for main effects.

\section{RESULTS}

Construction of the GFP strain. The transformation of Xf100-GFP was confirmed for the presence of GFPmut2 via PCR and sequencing. Inoculation with Xf100-GFP produced a similar number of lesions on leaves as the Xf100 wild type strain in greenhouse on all five strawberry cultivars tested (data not shown). Lesions on the abaxial surface of leaves were first observed at $7 \mathrm{~d}$ after leaf spray with $10^{8} \mathrm{CFU} / \mathrm{ml}$ of inoculum. The bacteria were able to maintain the p519ngfp plasmid over the course of the 8-week evaluation period as shown by the GFP signal in the bacterial colonies grown on agar plates (data not shown) and in the lesions on the live leaf tissues (Fig. 1A and B).

Spray inoculation. Leaves. For all three cultivars, the GFPlabeled bacteria applied by spray inoculation (SPR) produced the first visible leaf lesions at 1 wai. These subsequently coalesced to form the characteristic angular spots (Fig. 1A and B). The GFPlabeled bacteria were first seen in the leaf vascular bundles at 2 wai. The density of bacteria in strawberry tissues, determined by qPCR, reached its highest level of $10^{8}$ to $10^{9} \mathrm{CFU}$ per $100 \mathrm{mg}$ of tissue at 4 to 6 wai for both Festival and Darselect. This was 1,000 times higher than the starting concentration of inoculum on leaves (Fig. 2A and C). The bacteria density remained mostly stable throughout the remainder of the evaluation period; most inoculated leaves died by 12 wai. For all three cultivars, spray-inoculated leaves contained significantly higher densities of $X$. fragariae than the control (CON) according to analysis of qPCR results (Tables 1,2 , and $3 ; P<0.05$ ).

Petioles. GFP-labeled bacteria applied by spray inoculation to leaf tissue (SPR) were most frequently observed under the epidermis of the top $1 \mathrm{~cm}$ petiole section (Fig. 3A and B), and only once was it observed in the vascular bundle (6 wai in Festival). No bacteria were visually detected in the middle or bottom sections of petioles (Fig. 4A). The bacteria under the epidermis may be due in part to contamination that may have occurred during inoculation. Although inoculations were conducted carefully to reduce inadvertent inoculation of other plant tissues, some of the bacterial suspension still dripped on to the adjacent petiole. In these cases, the bacteria could enter the petiole directly through natural openings or wounds (e.g., lenticels or broken trichomes) and colonize the cells under the epidermis only (Fig. 3A to D). Evidence to support this argument was given by the detection of bacteria by qPCR in a number of the top petiole sections right after inoculation (0 wai) (Fig. 4A, C, and E).

Using qPCR, bacteria were detected in the top $1 \mathrm{~cm}$ petiole section of all three cultivars with densities between $10^{4}$ to $10^{6} \mathrm{CFU}$ (per section) in Festival and Ventana, and $10^{5}$ to $10^{7} \mathrm{CFU}$ in Darselect (Fig. 4). The petioles of spray-inoculated leaves (SPR) contained significantly higher levels of $X$. fragariae compared with the control (CON) for all cultivars according to analysis of qPCR results, with the exception of the bottom petiole sections for cultivar Ventana (Tables 1, 2 , and $3 ; P<0.05)$. However, compared with the top sections, very minimal bacteria ( $\sim$ detection limit to $10^{3} \mathrm{CFU} /$ sample) were detected in the bottom petiole sections of the inoculated leaves (Tables 1, 2, and 3).

Crowns. GFP-labeled bacteria applied by spray inoculation (SPR) were never observed in crown tissue for any cultivar at any sampling period. For all cultivars, qPCR quantification gave $C_{t}$ values equivalent to those of noninoculated control plants (Tables 1, 2, and 3; Fig. $2 \mathrm{~B}$, D, and F).

Wound inoculation. Leaves. Similar to spray inoculations (SPR), the earliest visible lesions for wound-inoculated leaves were seen at 1 wai. However, the characteristics of the lesions varied depending on the type of wounding (Fig. 1C to F; Tables 1 and 2; no wound inoculation treatments were applied to Ventana). For leaves inoculated by rubbing (RUB), classic ALS formed but there was noticeably more colonization of the leaf veins, which tended to be sparse for SPR. Characteristic angular spots did not develop on leaves with between-vein-infiltration inoculation (IBV). The bacteria were mainly confined to the infiltrated site between secondary veins or, in contrast, when directly infiltrated into secondary veins (IDV), the GFP signal was observed within veins as early as 1 wai and subsequently progressed along the vein. Similar to SPR, IDV-, RUB-, and IBV-inoculated leaves contained significantly higher levels of $X$. fragariae compared with $\mathrm{CON}$ according to qPCR analysis (Tables 1 and $2 ; P<0.05$ ). The bacteria density reached a maximum 
concentration of $10^{8}$ to $10^{9} \mathrm{CFU}$ per $100 \mathrm{mg}$ of tissue as early as 2 wai for infiltrated inoculation and at 8 to 10 wai for rub inoculation (Fig. 2A and C). These observations were characteristic for both Festival and Darselect. Some of the newly emerged leaves on inoculated plants (RUB-New in both cultivars and IBV-New in Festival) contained significantly higher levels of $X$. fragariae than $\mathrm{CON}$; however, the level of bacteria detected was minimum
( $\sim$ detection limit to $10^{3} \mathrm{CFU} / 100 \mathrm{mg}$ of tissue) (Tables 1 and 2; $P<0.05)$.

Petioles. GFP-labeled bacteria were most often observed to move from the site of inoculation into the top $1 \mathrm{~cm}$ section of petioles when bacteria were infiltrated directly into leaf veins (IDV) for both Festival and Darselect (Fig. 4A and C). In most cases, the GFP-labeled bacteria were found around the vascular
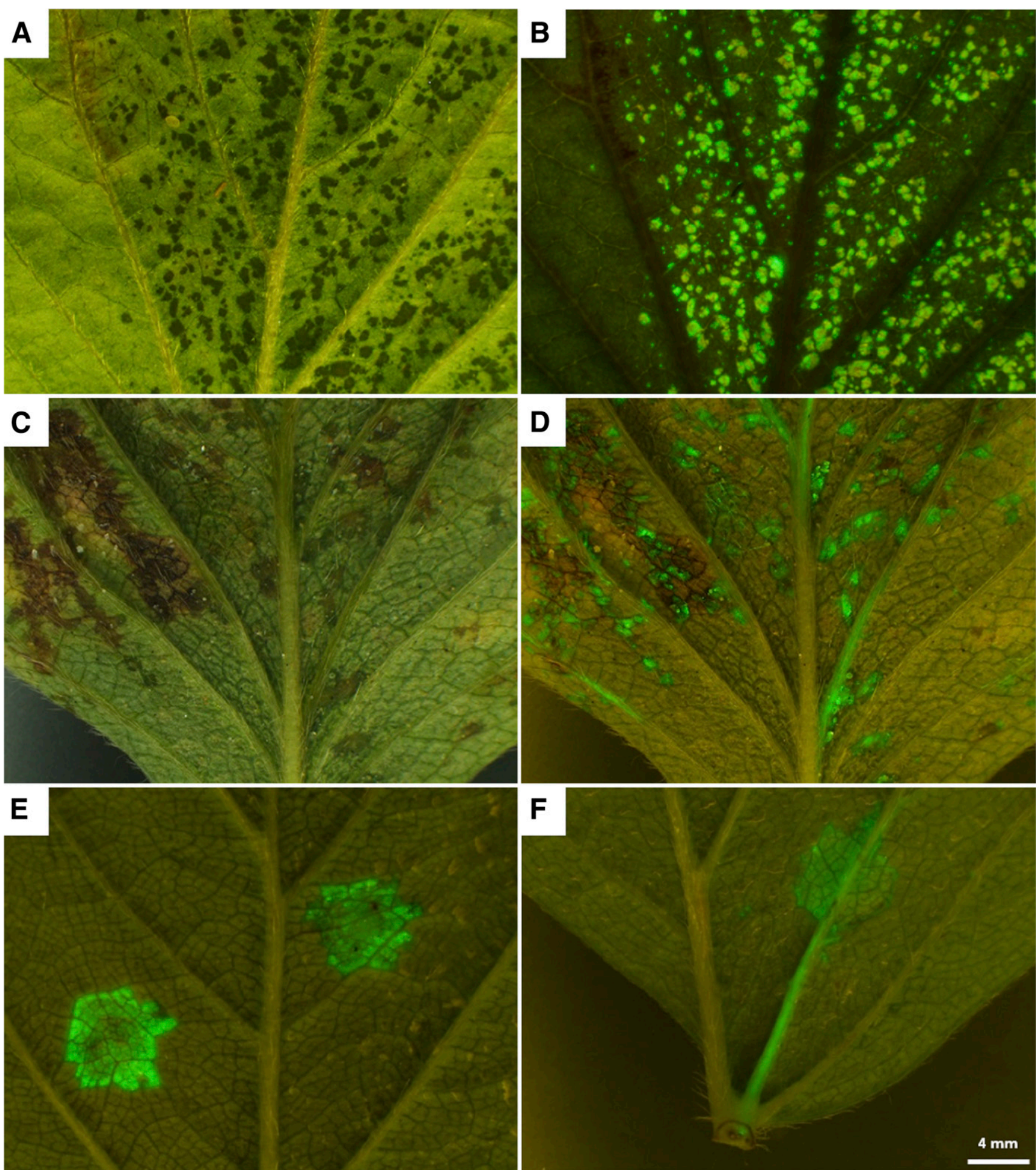

$\mathbf{F}$

Fig. 1. Leaf lesions morphologies for different inoculation methods of Xanthomonas fragariae: spray inoculation at 8 weeks after inoculation (wai) under A, white light and $\mathbf{B}$, blue light, respectively; rub inoculation at 8 wai under $\mathbf{C}$, white light and $\mathbf{D}$, blue light, respectively; $\mathbf{E}$, infiltration between side veins at 2 wai under blue light; and $\mathbf{F}$, infiltration directly into side veins at 2 wai under blue light. The same magnification was used for each picture and the scale bar was shown on panel F. 
bundle, occasionally colonizing the xylem vessels and seen only once in the phloem (Fig. 3E to H). For Darselect, bacteria infiltrated directly into veins (IDV) were observed in the petiole as early as 2 wai, 4 weeks earlier than observed in Festival. The bacterial densities in these $1 \mathrm{~cm}$ sections reached $10^{6}$ to $10^{8} \mathrm{CFU}$ per section (Fig. 4A and C). GFP-labeled bacteria were observed in the xylem of the middle petiole sections in three samples: one Darselect petiole at 8 wai and two Festival petioles at 12 wai (data not shown). Of these three petioles, the Festival sample with the highest bacterial density in the middle section $\left(\sim 4 \times 10^{8} \mathrm{CFU}\right)$ was the only petiole where bacteria were detected in the bottom section (by qPCR,
$5 \times 10^{4} \mathrm{CFU}$ ), although no GFP signal was observed in this bottom section.

In comparison, bacteria infiltrated in between secondary veins (IBV) were mainly confined in the inoculation site on leaves (Fig. 1E), but occasionally when the edge of the infiltration sites was close to a secondary vein, the bacteria were observed to colonize the secondary vein and move into the top petiole sections (1 Festival sample at 8 wai, and 1 Darselect sample at 8 and 10 wai each, Fig. 4A and C).

Similarly, for rub-inoculated plants (RUB), GFP-labeled bacteria were observed to move into the top $1 \mathrm{~cm}$ portion of petioles of two Festival leaves at 8 and 10 wai, the latter was also observed to have

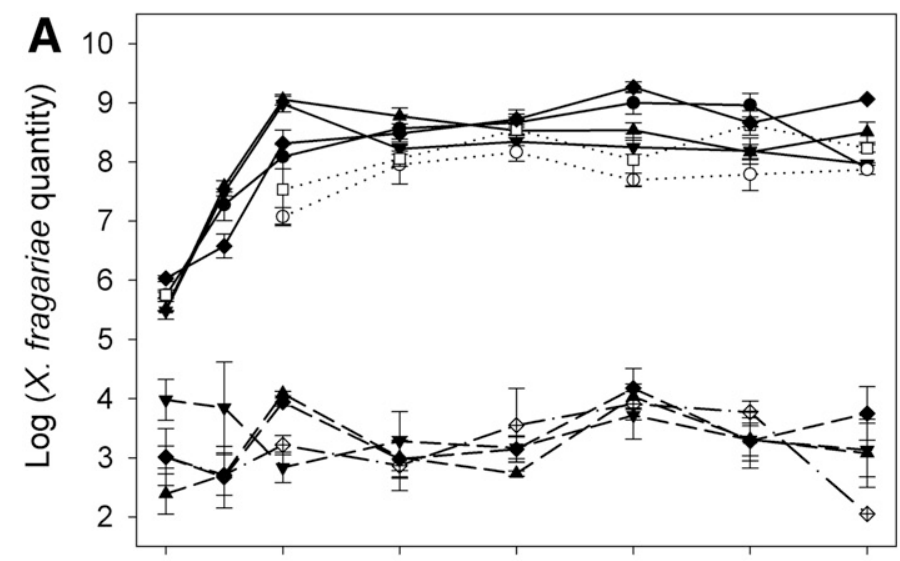

B
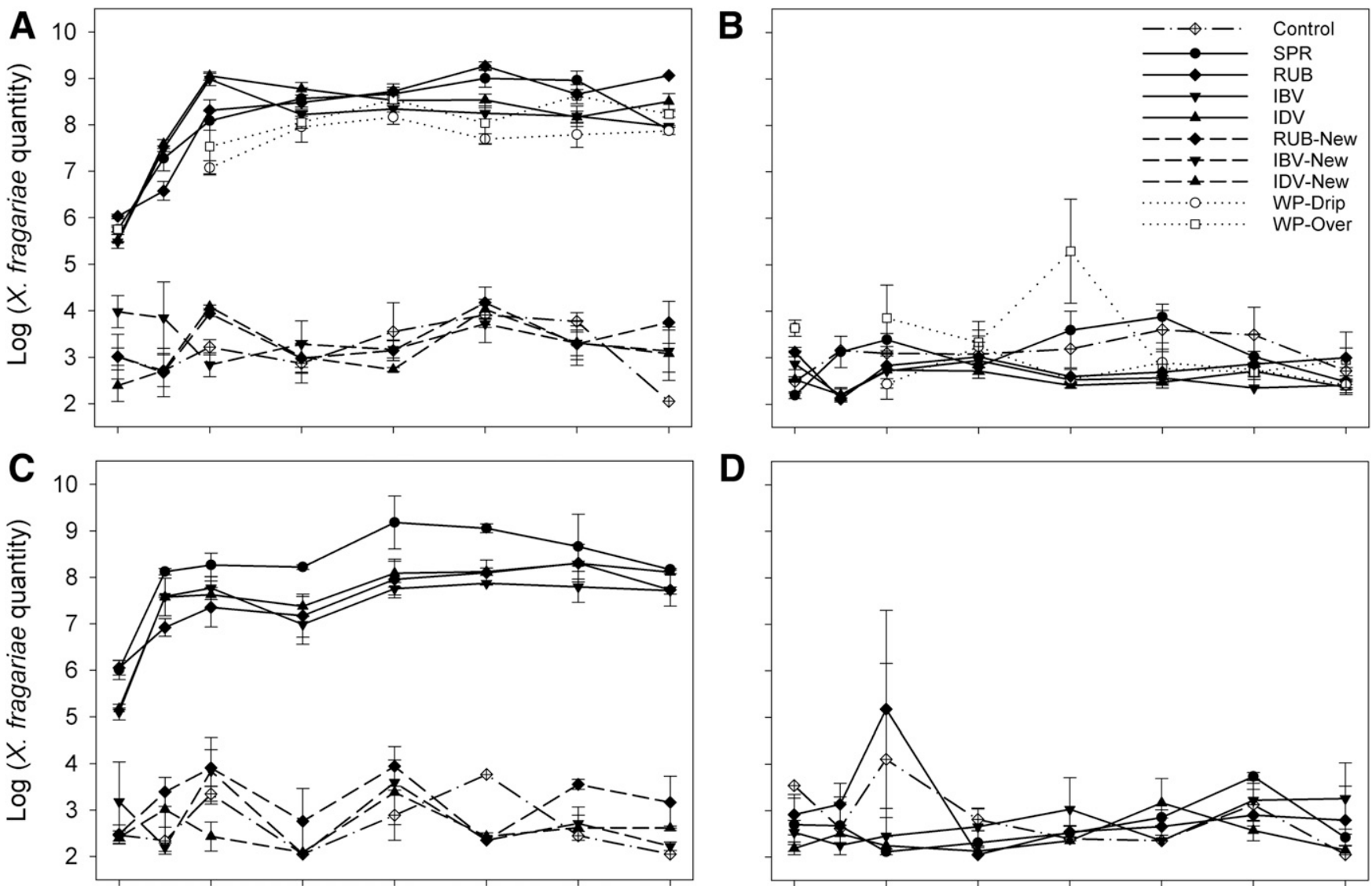

D
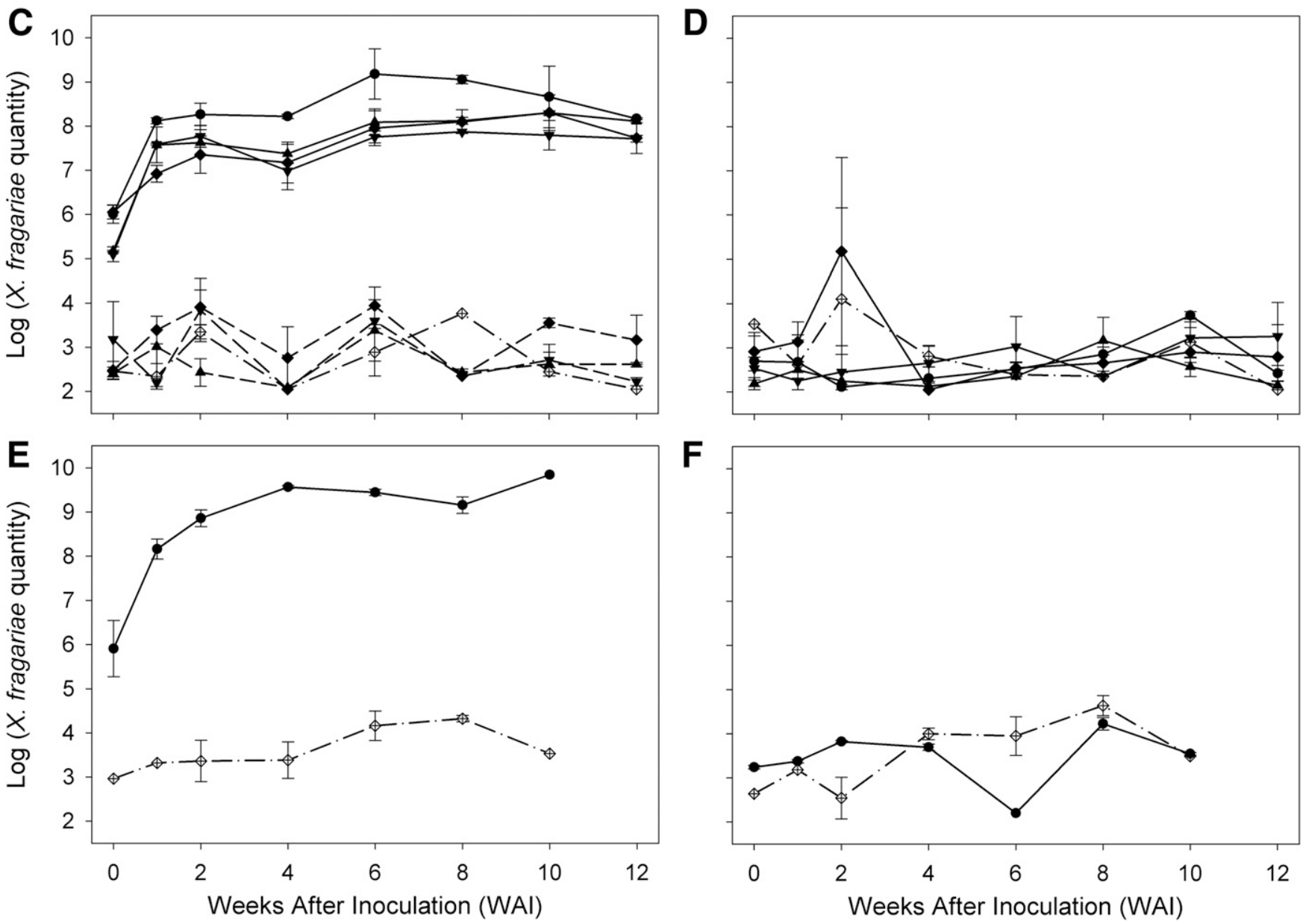

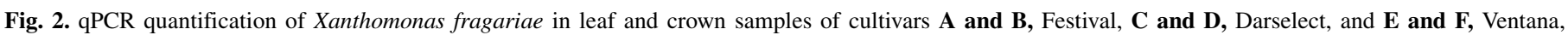

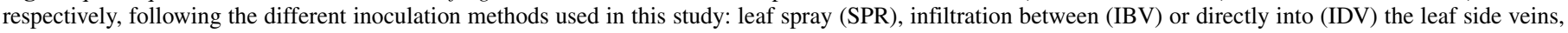

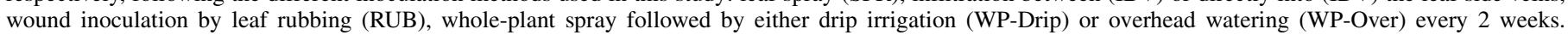

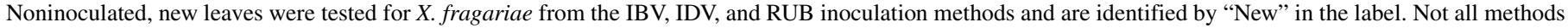
of inoculation were used on every cultivar. 
GFP-labeled bacteria in the middle, but not the bottom, petiole section (Fig. 4A). For these two cases, the wounds appeared to have been created very close to the side of a vein. No GFP-labeled bacteria were found in vascular bundle of any petioles of Darselect after rub inoculation.

For Festival, all of the petiole samples (including the newly emerged ones) tested from the wound-inoculated plants (IDV, RUB, and IBV) contained significantly higher levels of $X$. fragariae compared with those from the control plants $(\mathrm{CON})$ according to qPCR analysis (Table $1 ; P<0.05$ ). However, the concentration of bacteria detected in the bottom sections of petioles from the inoculated leaves and from the top, middle, and bottom sections of newly emerged petioles was low and near the qPCR detection limit ( $\sim$ detection limit to $10^{3} \mathrm{CFU}$ per sample).

For Darselect, significantly higher levels of $X$. fragariae were detected in the top petiole sections of all the inoculated leaves compared with the control (CON), according to analysis of qPCR results (Table $2 ; P<0.05$ ). The bottom petiole sections and newly emerged petioles produced mixed results, with only the RUB treatment having shown higher levels of $X$. fragariae than CON (Table 2; $P<0.05$ ); and the bacterial quantity was near the $\mathrm{qPCR}$ detection limit (103 CFU per sample). As mentioned above, no wound treatments were applied to Ventana.

Crown. GFP-labeled bacteria were never observed in crown tissue for any cultivar at any sampling period for wound inoculated

TABLE 1. Least square means ( \pm standard error) of the log of the number of colony forming units, estimated by qPCR, for strawberry plants (cultivar Festival) inoculated with a green fluorescent protein-labeled strain of Xanthomonas fragariae in leaf, petiole, and crown tissue ( 0 to 12 weeks after inoculation)

\begin{tabular}{llllc}
\hline Treatment $^{\mathrm{z}}$ & \multicolumn{1}{c}{ Leaves } & Petiole top & Petiole bottom & Crowns \\
\hline IDV & $8.14 \pm 0.14 \mathrm{a}$ & $6.25 \pm 0.17 \mathrm{a}$ & $3.34 \pm 0.14 \mathrm{c}$ & $2.52 \pm 0.14 \mathrm{c}$ \\
RUB & $8.07 \pm 0.15 \mathrm{a}$ & $6.54 \pm 0.17 \mathrm{a}$ & $3.80 \pm 0.14 \mathrm{~b}$ & $2.80 \pm 0.13 \mathrm{bc}$ \\
SPR & $8.04 \pm 0.12 \mathrm{a}$ & $4.48 \pm 0.14 \mathrm{~d}$ & $3.21 \pm 0.12 \mathrm{c}$ & $3.09 \pm 0.11 \mathrm{ab}$ \\
IBV & $7.85 \pm 0.14 \mathrm{ab}$ & $5.10 \pm 0.16 \mathrm{c}$ & $3.34 \pm 0.14 \mathrm{c}$ & $2.87 \pm 0.11 \mathrm{c}$ \\
WP-Over & $7.77 \pm 0.16 \mathrm{ab}$ & $6.55 \pm 0.18 \mathrm{a}$ & $4.77 \pm 0.15 \mathrm{a}$ & $3.44 \pm 0.15 \mathrm{a}$ \\
WP-Drip & $7.50 \pm 0.17 \mathrm{~b}$ & $5.64 \pm 0.18 \mathrm{~b}$ & $4.53 \pm 0.15 \mathrm{a}$ & $2.81 \pm 0.15 \mathrm{bc}$ \\
IBV-New & $3.41 \pm 0.14 \mathrm{c}$ & $3.35 \pm 0.17 \mathrm{e}$ & $3.33 \pm 0.14 \mathrm{c}$ & - \\
RUB-New & $3.37 \pm 0.14 \mathrm{c}$ & $3.45 \pm 0.16 \mathrm{e}$ & $3.47 \pm 0.13 \mathrm{bc}$ & - \\
IDV-New & $3.15 \pm 0.14 \mathrm{~cd}$ & $3.22 \pm 0.17 \mathrm{e}$ & $3.24 \pm 0.14 \mathrm{c}$ & - \\
CON & $2.83 \pm 0.18 \mathrm{de}$ & $2.54 \pm 0.21 \mathrm{f}$ & $2.56 \pm 0.17 \mathrm{~d}$ & $2.87 \pm 0.11 \mathrm{bc}$ \\
CON-WP & $2.39 \pm 0.19 \mathrm{e}$ & $2.25 \pm 0.22 \mathrm{f}$ & $2.37 \pm 0.18 \mathrm{~d}$ & $2.46 \pm 0.18 \mathrm{c}$ \\
\hline
\end{tabular}

$\mathrm{z}$ Treatment codes are as follows: $\mathrm{CON}=$ control; $\mathrm{CON}-\mathrm{WP}=$ whole-plant inoculation control; IBV = inoculation between leaf veins; IDV = inoculation directly into leaf vein; RUB = rub inoculation; $\mathrm{SPR}=$ spray inoculation; WP-Drip $=$ wholeplant inoculation followed by drip irrigation; and WP-Over $=$ whole-plant inoculation followed by overhead irrigation. Treatments followed by "New" refer to evaluations of noninoculated, newly emerged leaf tissue for presence of $X$. fragariae. Within each column, means sharing the same letter are not significantly different from each other $(P>0.05)$.

TABLE 2. Least square means ( \pm standard error) of the log of the number of colony forming units, estimated by qPCR, for strawberry plants (cultivar Darselect) inoculated with a green fluorescent protein-labeled strain of Xanthomonas fragariae in leaf, petiole, and crown tissue ( 0 to 12 weeks after inoculation)

\begin{tabular}{llllc}
\hline Treatment $^{\mathrm{z}}$ & \multicolumn{1}{c}{ Leaves } & \multicolumn{1}{c}{ Petiole top } & \multicolumn{1}{c}{ Petiole bottom } & \multicolumn{1}{c}{ Crowns } \\
\hline SPR & $8.21 \pm 0.16 \mathrm{a}$ & $5.90 \pm 0.18 \mathrm{a}$ & $3.60 \pm 0.15 \mathrm{a}$ & $2.66 \pm 0.21 \mathrm{a}$ \\
IDV & $7.51 \pm 0.17 \mathrm{~b}$ & $6.24 \pm 0.19 \mathrm{a}$ & $2.59 \pm 0.16 \mathrm{cde}$ & $2.41 \pm 0.21 \mathrm{a}$ \\
RUB & $7.45 \pm 0.16 \mathrm{~b}$ & $4.95 \pm 0.18 \mathrm{~b}$ & $3.16 \pm 0.15 \mathrm{~b}$ & $3.02 \pm 0.21 \mathrm{a}$ \\
IBV & $7.30 \pm 0.17 \mathrm{~b}$ & $4.91 \pm 0.19 \mathrm{~b}$ & $2.94 \pm 0.15 \mathrm{bcd}$ & $2.74 \pm 0.22 \mathrm{a}$ \\
RUB-New & $3.20 \pm 0.16 \mathrm{c}$ & $3.00 \pm 0.18 \mathrm{c}$ & $3.00 \pm 0.15 \mathrm{bc}$ & - \\
IBV-New & $2.81 \pm 0.17 \mathrm{~cd}$ & $2.58 \pm 0.18 \mathrm{~cd}$ & $2.58 \pm 0.15 \mathrm{de}$ & - \\
IDV-New & $2.62 \pm 0.16 \mathrm{~d}$ & $2.32 \pm 0.18 \mathrm{~d}$ & $2.32 \pm 0.15 \mathrm{e}$ & - \\
CON & $2.58 \pm 0.18 \mathrm{~d}$ & $2.53 \pm 0.21 \mathrm{~cd}$ & $2.52 \pm 0.17 \mathrm{de}$ & $2.91 \pm 0.24 \mathrm{a}$
\end{tabular}

$\mathrm{z}$ Treatment codes are as follows: $\mathrm{CON}=$ control; IBV $=$ inoculation between leaf veins; IDV = inoculation directly into leaf vein; RUB = rub inoculation; and $\mathrm{SPR}=$ spray inoculation. Treatments followed by "New" refer to evaluations of noninoculated, newly emerged leaf tissue for presence of $X$. fragariae. Within each column, means sharing the same letter are not significantly different from each other $(P>0.05)$. tissues. For all wound inoculations, qPCR quantification gave $\mathrm{C}_{\mathrm{t}}$ values equivalent to those of noninoculated control plants (Tables 1 and 2; Fig. 2B, D, and F).

Whole-plant inoculation (Festival only). Leaves. For whole-plant inoculations (WP-Over and WP-Drip), the bacteria colonization pattern on inoculated leaves was similar to those for individual leaf-spray inoculations (SPR). The first lesions colonized with GFP-labeled bacteria were found at 1 wai. Bacterial densities reached their peak at 6 wai and stayed relatively stable for the remainder of the evaluation period (Fig. 2A). At 6 to 12 wai, higher quantities of bacteria were detected in leaves on plants that were overhead irrigated once every 2 weeks than those that were drip irrigated. This was likely the result of the reinoculation that occurred with each overhead watering. The bacterial concentrations in leaf tissue for both whole-plant inoculation treatments were statistically greater than the control (CON-WP) (Table $1 ; P<0.05)$.

Petioles. GFP-labeled bacteria were mainly found under the epidermis of petiole sections for both WP-Over and WP-Drip treatments, which is expected from the direct spray inoculation on petioles (Fig. 3A, B). The starting bacterial densities in petioles after inoculation were $\sim 10^{5} \mathrm{CFU}$ per section, and remained constant throughout the evaluation period for both the middle and bottom petiole sections (Fig. 4A). In contrast, the average bacteria densities in the top petiole sections increased to $\sim 10^{6} \mathrm{CFU}$ at 10 wai in drip-irrigated plants (WP-Drip), and up to $10^{7}$ to $10^{8} \mathrm{CFU}$ during 8 to 12 wai in overhead-irrigated plants (WPOver). At the time points where bacteria densities reached their peak in the top petiole sections (measured by qPCR), GFP-labeled bacteria were also observed in the vascular bundle of the petioles (Fig. 4A). The bacterial concentrations in the top and bottom petiole tissues for both whole-plant inoculation treatments were significantly greater than the control (CON-WP) according to analysis of qPCR results (Table $1 ; P<0.05$ ). For the bottom petiole section, WP-Over and WP-Drip had the greatest concentration of bacteria among all the inoculation treatments (Table $1 ; P<0.05$ ).

Crown. Bacteria were detected in crown tissue by qPCR at 6 wai ( $\sim 10^{7} \mathrm{CFU}$ per section) on two plants treated by overhead irrigation (Fig. 2C). The bacterial concentrations in crown tissues was statistically greater than CON-WP for WP-Over but not for WPDrip according to analysis of qPCR results (Table $1 ; P<0.05$ ).

\section{DISCUSSION}

As the causal agent of ALS of strawberry, $X$. fragariae has been inferred to be a systemic pathogen (Bestfleisch et al. 2015; Hildebrand et al. 1967; Kastelein et al. 2014; Maas 1984; Milholland et al. 1996; Stefani et al. 1989; Turechek et al. 2008). The inference of systemic movement implies an active process that begins with invasion of the vascular tissue, leading to significant pathogen colonization of the plant, and is normally followed by symptoms characteristic of a compromised vascular system, most notably, wilting and collapse. These symptoms are not typical of ALS, yet not unheard of. Hildebrand et al. (1967) were the first to describe the systemic invasion of $X$. fragariae. Their article "calls attention to evidence that ALS and vascular collapse or decline are both caused by $X$. fragariae, and are different manifestations of the same disease."

TABLE 3. Least square means ( \pm standard error) of the $\log$ of the number of colony forming units, estimated by qPCR, for strawberry plants (cultivar Ventana) inoculated with a green fluorescent protein-labeled strain of Xanthomonas fragariae in leaf, petiole, and crown tissue ( 0 to 10 weeks after inoculation)

\begin{tabular}{lcccc}
\hline Treatment $^{\mathrm{z}}$ & Leaves & Petiole top & Petiole bottom & Crowns \\
\hline SPR & $8.67 \pm 0.21 \mathrm{a}$ & $4.84 \pm 0.17 \mathrm{a}$ & $3.75 \pm 0.09 \mathrm{a}$ & $3.44 \pm 0.14 \mathrm{a}$ \\
CON & $3.50 \pm 0.18 \mathrm{~b}$ & $3.27 \pm 0.20 \mathrm{~b}$ & $3.50 \pm 0.10 \mathrm{a}$ & $3.55 \pm 0.17 \mathrm{a}$ \\
\hline
\end{tabular}

$\mathrm{z}$ Treatment codes are as follows: $\mathrm{CON}=$ control; and $\mathrm{SPR}=$ spray inoculation. Within each column, means sharing the same letter are not significantly different from each other $(P>0.05)$. 
Over the last 30 years, at least three studies have been conducted that sought to better characterize the infection process and systemic movement of $X$. fragariae in the plant (Bestfleisch et al. 2015; Milholland et al. 1996; Stefani et al. 1989). Each of these studies advanced our understanding of the infection process but, individually, none provided clear evidence to explain why $X$. fragariae was sometimes confined to the foliage and why other times it was found colonizing the vascular tissue. Stefani et al. (1989) identified $X$. fragariae in petiole tissue up to $3 \mathrm{~cm}$ away from the inoculation point, scarcely what one would consider systemic movement. However, their results should be interpreted cautiously because, despite having cut away the water-soaked halos around each lesion, the authors washed the leaves with water before processing, which likely redistributed bacteria across the entire leaf surface. Further, detection
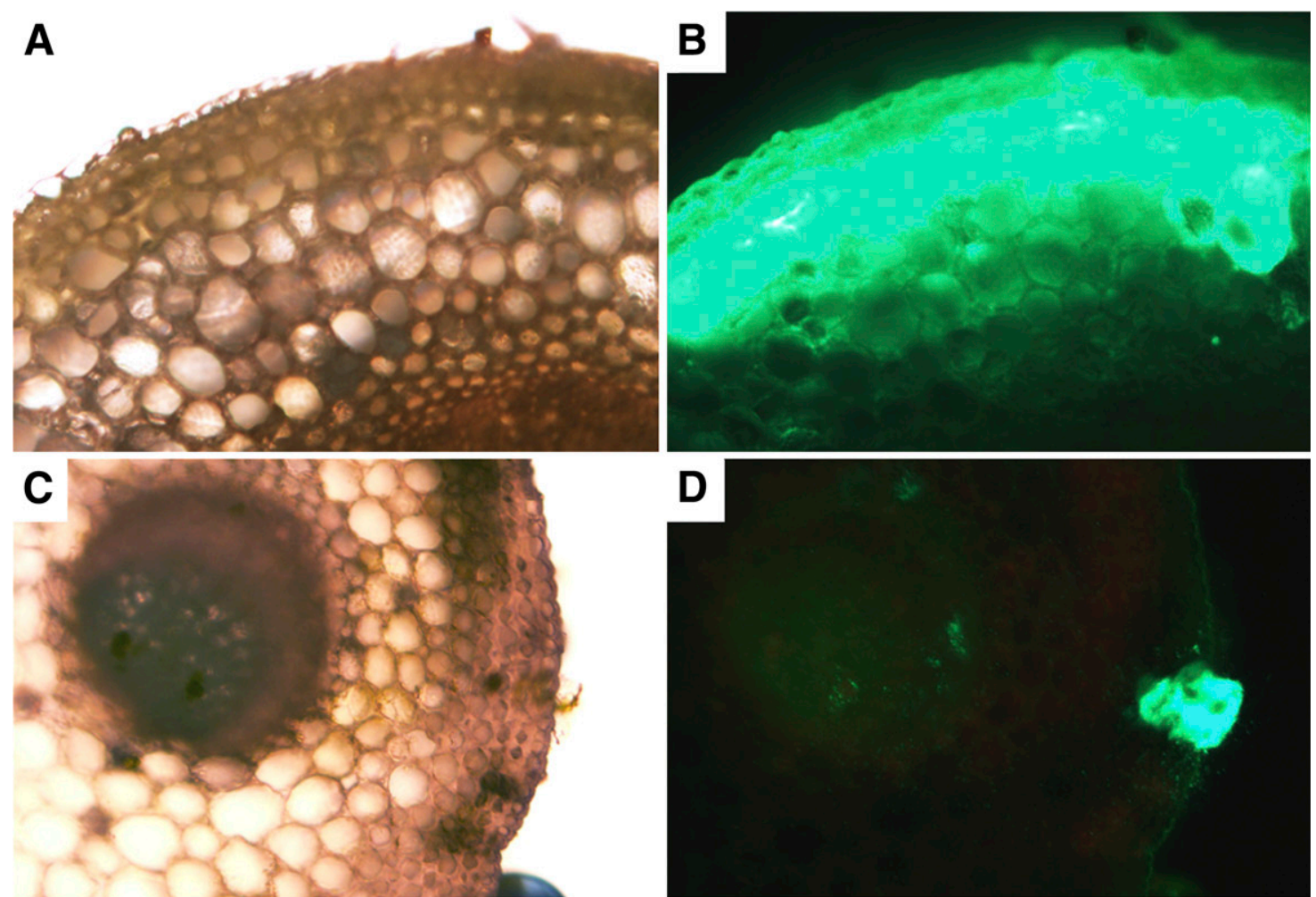

D
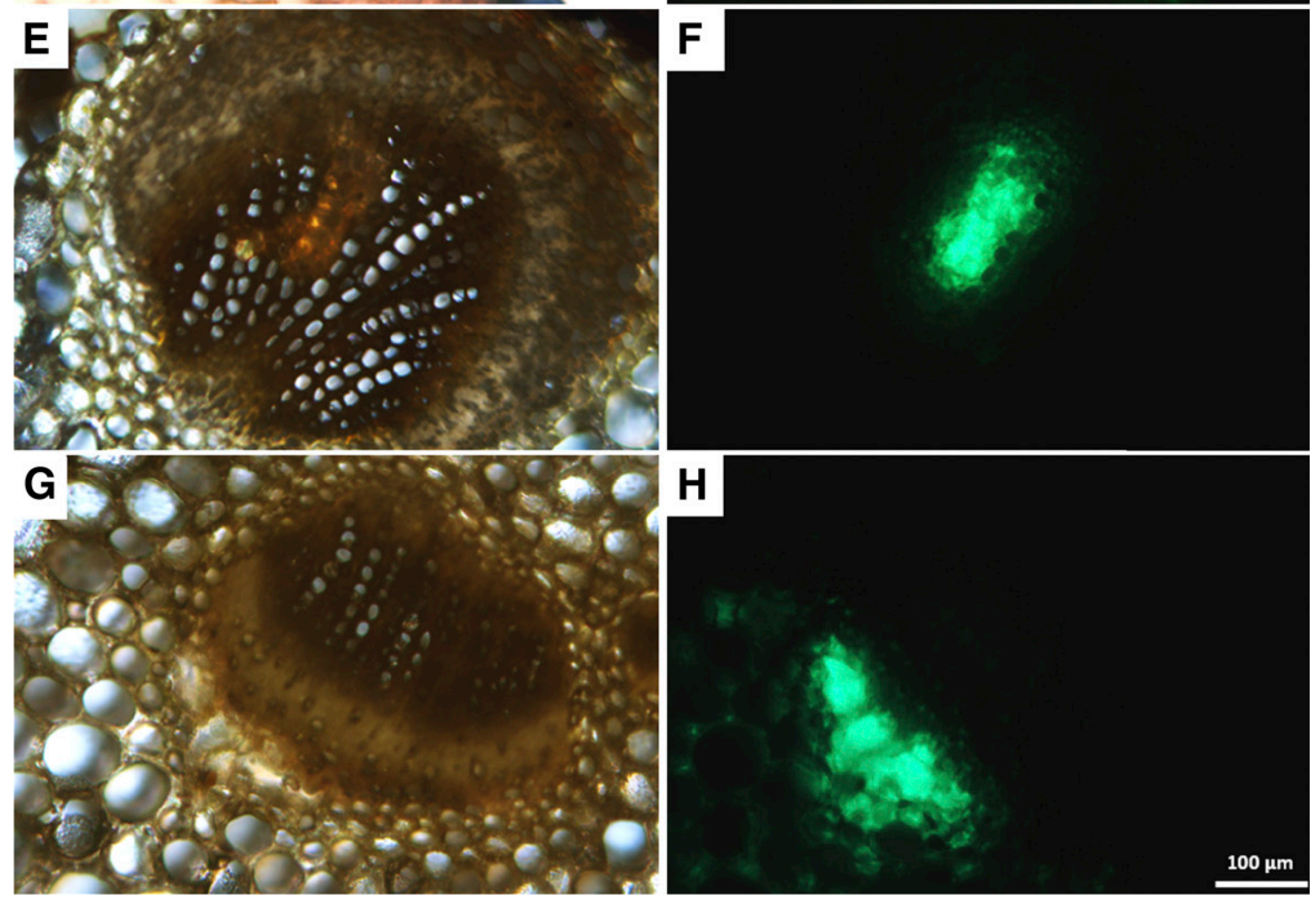

Fig. 3. Cross sections of strawberry petioles after inoculation of Xanthomonas fragariae strain Xf100-GFP under white light and blue light (left and right panels, respectively): A and B, bacteria colonizing under the epidermis of petiole at 6 weeks after inoculation (wai); $\mathbf{C}$ and $\mathbf{D}$, bacteria aggregating around a trichome on the petiole at 1 wai; $\mathbf{E}$ and $\mathbf{F}$, bacteria colonizing the xylem of petiole at 8 wai; and $\mathbf{G}$ and $\mathbf{H}$, bacteria colonizing the bundle sheath and phloem of petiole at 2 wai. The same magnification was used for each picture and the scale bar was shown on panel $\mathrm{H}$. 
was based strictly on IFAS, which had limited specificity as evidenced by the author's consistent use of the phrase "similar to X. fragariae" to refer to target colonies; no histological examinations were conducted.

Similar to our study, Bestfleisch et al. (2015) used a GFP-labeled strain and nested PCR to evaluate the movement of $X$. fragariae. Bestfleisch et al. (2015) tested a range of cultivars and selected both noninoculated and inoculated leaves and petioles, rhizomes [sic] and the "heart bud" for visual examination and PCR testing. GFP signal was visualized in the leaf veins at 3 dai and a representative gel from their PCR testing showed a band for every tissue tested at 3 , 7 and 14 dai, providing evidence of vascular tissue invasion and systemic movement. These results were different than what was found in our experiments, as well as others. For X. fragariae, such a rapid and extensive movement through the plant is unprecedented. Milholland et al. (1996), for example, did not detect bacteria in roots or runners until 6 wai, and not in crown tissue until 8 wai. However, of the 145 (genotypes) $\times 4$ (plants) tested by Bestfleisch et al.
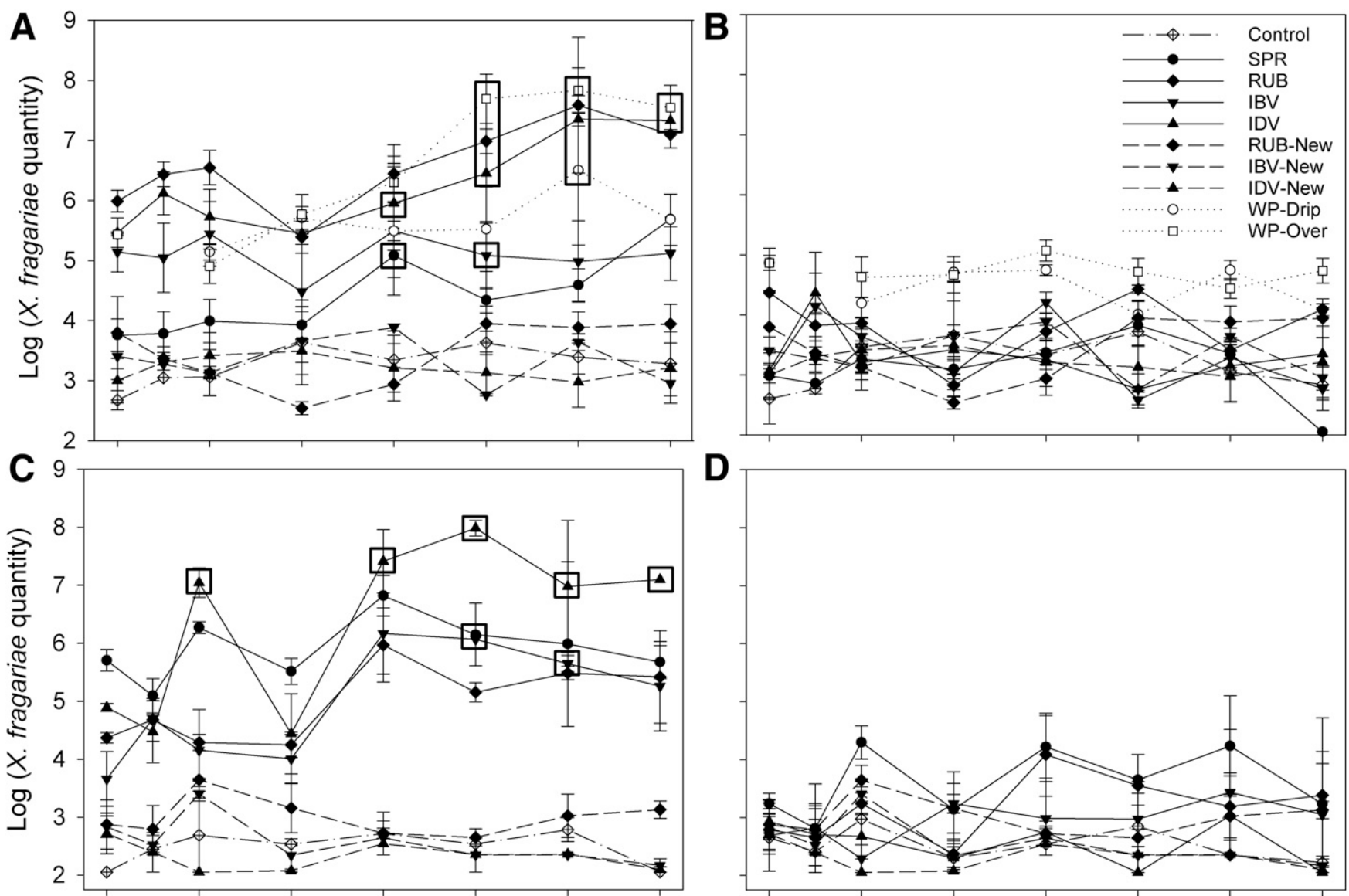

D
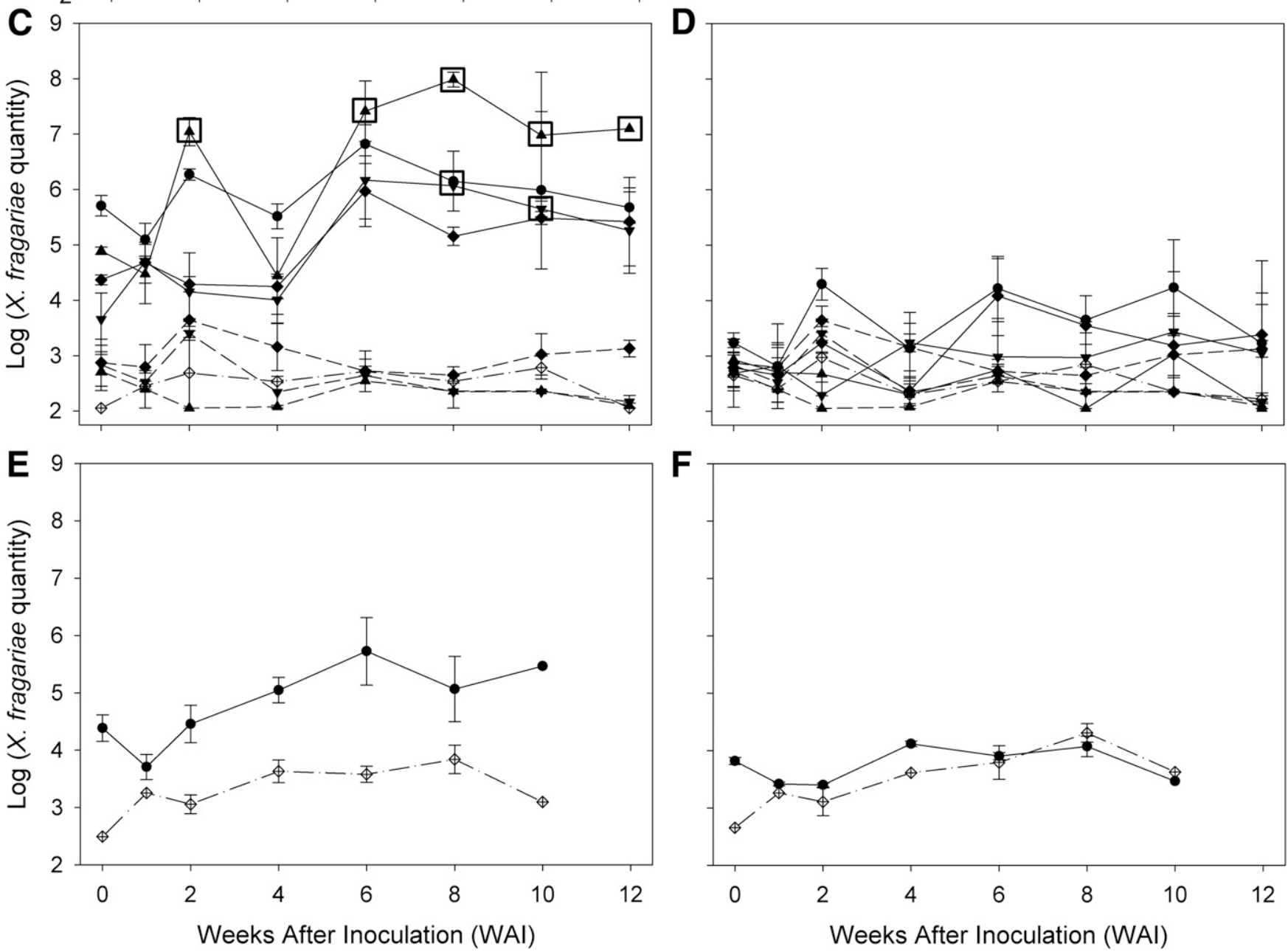

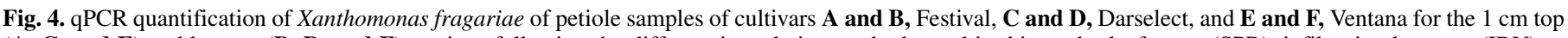

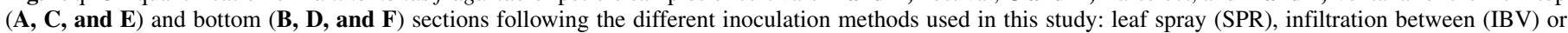

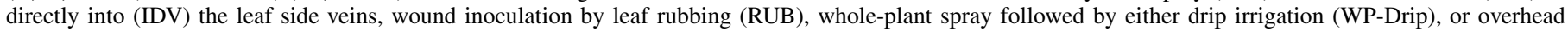

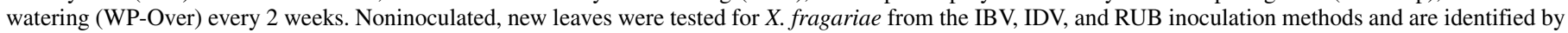

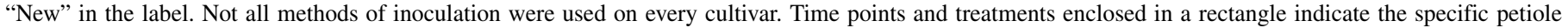
sections where the green fluorescent protein strain was seen along the vascular tissue all the way down from leaves. 
(2015), it was not made clear what proportion of plants were colonized this rapidly, but it was reported that at 28 dai $X$. fragariae was present in all samples tested by nested PCR. One cannot, however, rule out the possibility of contamination, as the plants were rub-inoculated and then covered with plastic tunnels with high humidity for 3 to 5 days to induce guttation. Guttation can be quite extensive in strawberry, and the numerous droplets of water present at the tips of each leaflet can be easily dislodged and inoculate other plant tissues. Contamination is also a concern in the study of Milholland et al. (1996) where plants with rub-inoculated leaves were placed in plastic bags for 10 days.

Milholland et al. (1996) conducted histological examinations and noted that bacteria accumulated beneath the epidermal cells of leaf tissue and could also be found in the vessel elements in petiole tissue 4, 6, and 8 wai. This somewhat contrasts to Allan-Wojtas et al. (2010), who after 18 days (clearly less than 4 weeks) found no bacteria in the vascular tissue of the leaves after using several microscopy techniques. Allan-Wojtas et al. (2010) did speculate that bacteria must somehow invade the vascular tissue given reports that the bacteria can be recovered from crown tissue (most likely referring to the work of Milholland et al. (1996) and/or Hildebrand et al. (1967).

In contrast to this prior work, a recent review of the Xanthomonads classified $X$. fragariae as a nonvascular pathogen (Jacques et al. 2016). In general, it is believed that Xanthomonas spp. infect plants by colonizing the intercellular spaces of the mesophyll parenchyma cells or by colonizing the vascular tissues, or sometimes both (Jacques et al. 2016; Pfeilmeier et al. 2016; Ryan et al. 2011). When vascular pathogens cause systemic infection in plants the associated disease symptoms are usually blight, wilt, and rot. As noted above, $X$. fragariae does not typically cause these symptoms, but rather it colonizes the intercellular space of leaf mesophyll like the other leaf spot causing bacteria (Allan-Wojtas et al. 2010; Jacques et al. 2016; Kastelein et al. 2014). Indeed, genome sequences of $X$. fragariae revealed the absence of genes for degradation of xylan and lignin, two important elements of plant secondary cell wall structure including the highly lignified vessel elements, suggesting the confinement of this bacterium in nonvascular tissues (Vandroemme et al. 2013).

In the current study, a GFP-labeled strain was used to re-evaluate the infection, multiplication, and movement of $X$. fragariae in strawberry plants. Large sample sizes, different inoculation methods, and three strawberry cultivars to varying degrees were utilized to determine the likelihood of and identify the conditions that lead to systemic infection. Not completely unexpected, $X$. fragariae was found to mainly colonize the leaf mesophyll and populations increased up to 1,000 times within 6 wai to reach $10^{8}$ to $10^{9} \mathrm{CFU}$ per $100 \mathrm{mg}$ of tissue, which closely matched results of Milholland et al. (1996). Different inoculation methods produced lesions of different appearances, but they shared similar patterns of multiplication in leaf tissue (Figs. 1 and 2A, C, and E). The GFP strain was also able to invade the leaf vein in some instances and move passively along the vascular tissues (mostly in bundle sheath and xylem vessels). Intercellular movement from the mesophyll through parenchyma of the bundle sheath into xylem and phloem tissues has been reported for other Xanthomonads (Shekhawat et al. 1977). Based on microscopic observation, the GFP-labeled bacteria were only able to move a limited distance from infected leaves into the adjacent petiole sections along the vascular bundle (mainly the top $1 \mathrm{~cm}$ sections), similar to Stefani et al. (1989), but this movement was usually not observed until after 6 wai. The density of bacteria in these top petiole sections closely matched with the densities in petioles of inoculated leaves reported by Milholland et al. (1996) (Fig. 4). When the bacteria colonized xylem vessels, they tended to travel beyond the top section and into the middle of petioles. Similar findings have been reported for other leaf spot-causing Xanthomonads where the furthest moving bacteria (within a petiole) were found to have entered the xylem vessels (Aarrouf et al. 2008; Barak et al. 2002). Wound inoculation, especially when the bacteria were directly infiltrated into leaf veins, increased the likelihood of systemic movement of bacteria along the vascular bundle.

The systemic movement of GFP-labeled bacteria to crown tissue or to the bottom sections of the petioles adjacent to inoculated leaves was not observed; however, bacteria were able to directly enter and colonize these tissues through wounds and openings without causing symptoms. In this study, colonization of GFPlabeled bacteria under the epidermis of petioles was observed with whole-plant inoculations; bacteria were witnessed to aggregate around the trichome, which is a nutrient-rich spot for epiphytic survival of bacteria and an entry point into petiole tissue when broken (Fig. 3) (Melotto et al. 2008). The bacteria directly entering petioles remained at a constant density throughout the time course of sampling, without causing disease symptoms. In the field, microwounds caused by wind and wind-blown sand combined with overhead watering could create entry points for the bacteria on nearly all above ground tissues and may promote infection of tissues other than leaf tissue, which may be possibly misconstrued for systemic movement through vascular tissues. Hildebrand et al. (1967) reported some extreme cases of vascular collapse when large quantities of bacteria were found in crown from the field samples, but also stated that the bacteria colonization of crown was normally not detectable without dissecting and destroying the plant. The mechanism and conditions leading to systemic invasion and infection of the crown and what Hildebrand et al. (1967) refer to as this "alternative manifestation of disease" remains largely speculative.

Plants that were wholly inoculated (i.e., whole-plant inoculations), particularly those that were overhead irrigated, had a greater likelihood of petiole infection than those subjected to simple leaf inoculations and drip irrigated. The large quantity of bacteria inoculated onto the entire plant plus the redistribution and reinoculation that occurs with each overhead watering event facilitated widespread infection of all plant tissues. And only with the overhead irrigation were the bacteria detected in crown tissue (at 2 wai). But for this plant, no bacteria was detected in the vascular bundle of petioles, which is likely an indication that the bacteria were splashed directly onto the crown during watering, rather than having moved into the crown by systemic movement through the vascular systems from leaf infections. However, crown infections were not seen with every plant subjected to overhead irrigation. It is possible that other factors interfere with the infection process, e.g., microorganisms outcompeted $X$. fragariae at the soil interface where the crown tissue is located or that wounds may need to be present for crown tissue to be infected.

With the exception of the single, overhead irrigation treatment, all other treatments were drip irrigated. For these treatments, no bacteria were seen in the bottom petiole sections of the inoculated leaves, crown, and any uninoculated leaves of all the cultivars tested. The bacteria quantity in these tissues determined by qPCR was very minimal (close to the qPCR detection limit to $10^{3} \mathrm{cfu} /$ sample, Table 1, 2, and 3). These results were in contrast to those reported by Bestfleisch et al. (2015). One of the main differences in the methodologies between this study and theirs was that the plants in this study were not kept in plastic tunnels with high humidity to induce guttation. We wanted to eliminate the presence of free water on leaf surfaces to prevent cross contamination of uninoculated plant tissues. In a preliminary experiment, we induced guttation and added $10 \mu \mathrm{l}$ of GFP-labeled bacteria $\left(\sim 10^{8} \mathrm{CFU} / \mathrm{ml}\right)$ to each guttation droplet without dripping onto leaf surfaces to examine the extent to which bacteria moved through the hydathodes. However, no bacteria movement into the leaf vascular tissue was ever observed in our studies (data not shown).

Based on our findings, we suggest that $X$. fragariae is capable of moving into uninoculated plant parts along the vascular bundle but the systemic movement is a passive process. Any process that allows direct entry in the vascular tissue, such as wounding of the leaf veins, was able to encourage more extensive colonization of the vascular tissue and movement of the bacteria from leaves into the adjacent petioles. However, even when the bacteria were directly infiltrated 
into leaf veins, the movement of $X$. fragariae to uninoculated leaves, existing or newly formed, was never observed in this study. Given that the majority of leaves are removed from the nursery stock (leaving the petioles attached to the plant) and that bacteria survive on plant tissues during cold storage (Hildebrand et al. 1967), it is likely that petioles are an important source of inoculum. Indeed, Turechek et al. (2013) provided evidence that showed removal of the remnant petiole tissue on cold-stored plants can reduce ALS in the field. The practice of removing petioles to the extent that was done in Turechek et al. (2013) is impractical on a commercial scale; however, the experiment gave credence to the fact that bacteria survive long term in petiole tissue. Development of new strategies to target the bacteria source in petioles, as well as preventing overhead irrigation and wounding of plant tissues, would further limit the frequency of infection and dispersal of $X$. fragariae to other healthy tissues, which will contribute to better disease management.

\section{ACKNOWLEDGMENTS}

We thank G. Hess, R. Brown, and K. Poole for their highly skilled technical assistance.

\section{LITERATURE CITED}

Aarrouf, J., Garcin, A., Lizzi, Y., and Maâtaoui, M. E. 2008. Immunolocalization and histocytopathological effects of Xanthomonas arboricola pv. pruni on naturally infected leaf and fruit tissues of peach (Prunus persica $\mathrm{L}$. Batsch). J. Phytopathol. 156:338-345.

Aiello, D., Scuderi, G., Vitale, A., Firrao, G., Polizzi, G., and Cirvilleri, G. 2013. A pith necrosis caused by Xanthomonas perforans on tomato plants. Eur. J. Plant Pathol. 137:29-41.

Allan-Wojtas, P., Hildebrand, P. D., Braun, P. G., Smith-King, H. L., Carbyn, S., and Renderos, W. E. 2010. Low temperature and anhydrous electron microscopy techniques to observe the infection process of the bacterial pathogen Xanthomonas fragariae on strawberry leaves. J. Microsc. 239:249-258.

Barak, J. D., Koike, S. T., and Gilbertson, R. L. 2002. Movement of Xanthomonas campestris pv. vitians in the stems of lettuce and seed contamination. Plant Pathol. 51:506-512.

Bestfleisch, M., Richter, K., Wensing, A., Wünsche, J. N., Hanke, M. V., Höfer, M., Schulte, E., and Flachowsky, H. 2015. Resistance and systemic dispersal of Xanthomonas fragariae in strawberry germplasm (Fragaria L.). Plant Pathol. 64:71-80.

Gigot, C., Turechek, W. W., and McRoberts, N. 2017. Analysis of the spatial pattern of strawberry angular leaf spot in California nursery production. Phytopathology 107:1243-1255.

Hayward, A. C. 1960. A method for characterizing Pseudomonas solanacearum. Nature 186:405-406.

Hazel, W. J., and Civerolo, E. L. 1980. Procedures for growth and inoculation of Xanthomonas fragariae, causal organism of angular leaf spot of strawberry. Plant Dis. 64:178-181.

Hildebrand, D. C., Schroth, M. N., and Wilhelm, S. 1967. Systemic invasion of strawberry by Xanthomonas fragariae causing vascular collapse. Phytopathology 57:1260-1261.

Hildebrand, P. D., Braun, P. G., Renderos, W. E., Jamieson, A. R., McRae, K. B., and Binns, M. R. 2005. A quantitative method for inoculating strawberry leaves with Xanthomonas fragariae, factors affecting infection, and cultivar reactions. Can. J. Plant Pathol. 27:16-24.

Jacques, M. A., Arlat, M., Boulanger, A., Boureau, T., Carrère, S., Cesbron, S., Chen, N. W., Cociancich, S., Darrasse, A., and Denancé, N., Fischer, S. M.,
Gagnevin, L., Koebnik, R., Lauber, E., Noël, L. D., Pieretti, I., Portier, P., Pruvost, O., Rieux, A., Robène, I., Royer, M., Szurek, B., Verdier, V., and Vernière, C. 2016. Using ecology, physiology and genomics to understand host specificity in Xanthomonas. Annu. Rev. Phytopathol. 54:163-187.

Kastelein, P., Krijger, M., Czajkowski, R., van der Zouwen, P. S., van der Schoor, R., Jalink, H., and van der Wolf, J. M. 2014. Development of Xanthomonas fragariae populations and disease progression in strawberry plants after spray-inoculation of leaves. Plant Pathol. 63:255-263.

López, M. M., Domínguez, F., Morente, C., Salecedo, C. I., Olmos, A., and Civerolo, E. 2006. Xanthomonas fragariae. OEPP/EPPO Bull. 36:135-144.

Maas, J., Pooler, M., and Galleta, G. 1995. Bacterial angular leaf spot disease of strawberry: Present status and prospects for control. Adv. Strawb. Res. 14:18-24.

Maas, J. L. 1984. Compendium of Strawberry Diseases. American Phytopathology Society, St. Paul, MN.

Matthysse, A. G., Stretton, S., Dandie, C., McClure, N. C., and Goodman, A. E. 1996. Construction of GFP vectors for use in gram-negative bacteria other than Escherichia coli. FEMS Microbiol. Lett. 145:87-94.

Melotto, M., Underwood, W., and He, S. Y. 2008. Role of stomata in plant innate immunity and foliar bacterial diseases. Annu. Rev. Phytopathol. 46: 101-122.

Milholland, R. D., Ritchie, D. F., Daykin, M. E., and Gutierrez, W. A. 1996. Multiplication and translocation of Xanthomonas fragariae in strawberry. Adv. Strawb. Res. 15:13-17.

Pfeilmeier, S., Caly, D. L., and Malone, J. G. 2016. Bacterial pathogenesis of plants: Future challenges from a microbial perspective. Mol. Plant Pathol. 17:1298-1313.

Pooler, M. R., Ritchie, D. F., and Hartung, J. S. 1996. Genetic relationships among strains of Xanthomonas fragariae based on random amplified polymorphic DNA PCR, repetitive intergenic consensus PCR data and generation of multiplexed PCR primers useful for the identification of this phytopathogen. Appl. Environ. Microbiol. 62:3121-3127.

Ryan, R. P., Vorhölter, F. J., Potnis, N., Jones, J. B., Van Sluys, M. A., Bogdanove, A. J., and Dow, J. M. 2011. Pathogenomics of Xanthomonas: Understanding bacterium-plant interactions. Nat. Rev. Microbiol. 9: 344-355.

Shekhawat, G. S., Patel, P. N., and Raj, S. 1977. Histology of cowpea plants infected with Xanthomonas viginicola. J. Plant Dis. Prot. 84:547-558.

Smith, I. M., McNamar, D. G., Scott, P. R., and Harris, K. M. (eds.) 1992. Quarantine pests for Europe. Pages 829-833 in: Data Sheets on European Communities and for the European and Mediterranean Plant Protection Organization. CAB International, Wallingford, Oxon.

Stefani, E., Mazzucchi, U., and Calzolari, A. 1989. Evidence of endophytic movement of Xanthomonas fragariae Kenn. and King in strawberry. Phytopathol. Mediterr. 28:147-149.

Turechek, W. W., Hartung, J. S., and McCallister, J. 2008. Development and optimization of a real-time detection assay for Xanthomonas fragariae in strawberry crown tissue with receiver operating characteristic (ROC) curve analysis. Phytopathology 98:359-368.

Turechek, W. W., Wang, S., Tiwari, R., and Peres, N. A. 2013. Investigating alternative strategies for managing bacterial angular leaf spot in strawberry nursery production. Int. J. Fruit Sci. 13:234-245.

Vandroemme, J., Cottyn, B., Baeyen, S., De Vos, P., and Maes, M. 2013. Draft genome sequence of Xanthomonas fragariae reveals reductive evolution and distinct virulence-related gene content. BMC Genomics 14:829.

Wang, H., and Turechek, W. W. 2016. A loop-mediated isothermal amplification assay and sample preparation procedure for sensitive detection of Xanthomonas fragariae in strawberry. PLoS One 11:e0147122.

Zimmermann, C., Hinrichs-Berger, J., Moltmann, E., and Buchenauer, H. 2004. Nested PCR (polymerase chain reaction) for detection of Xanthomonas fragariae in symptomless strawberry plants. J. Plant Dis. Prot. 111: $39-51$ 